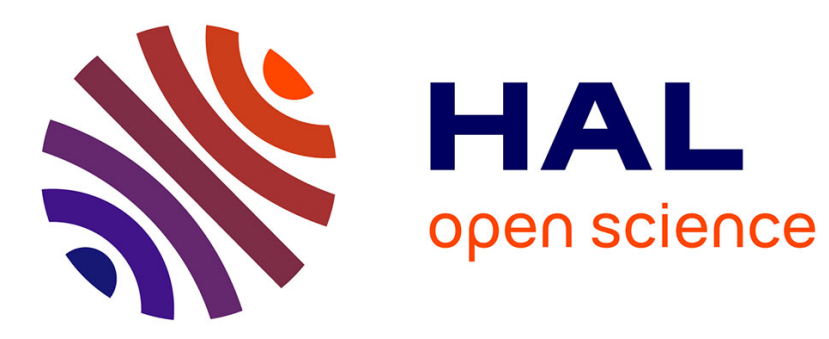

\title{
The Television Channel ARTE as a Time Machine and Matrix for European Identity
}

\author{
Aline Hartemann
}

\section{To cite this version:}

Aline Hartemann. The Television Channel ARTE as a Time Machine and Matrix for European Identity. Palgrave Mac Millan Memory Studies; Katharina Niemeyer. Media and Nostalgia: yearning for the Past, the Present and the Future. Katharina Niemeyer ed., Palgrave Mac Millan UK, 2014, 10.1057/9781137375889.0019. halshs-01314382

\section{HAL Id: halshs-01314382 \\ https://shs.hal.science/halshs-01314382}

Submitted on 11 May 2016

HAL is a multi-disciplinary open access archive for the deposit and dissemination of scientific research documents, whether they are published or not. The documents may come from teaching and research institutions in France or abroad, or from public or private research centers.
L'archive ouverte pluridisciplinaire HAL, est destinée au dépôt et à la diffusion de documents scientifiques de niveau recherche, publiés ou non, émanant des établissements d'enseignement et de recherche français ou étrangers, des laboratoires publics ou privés. 


\section{The Television Channel ARTE as a Time Machine and}

\section{Matrix for European Identity}

\section{Aline Hartemann}

This chapter examines the French-German, European-oriented, cultural television channel ARTE and its roles as a 'nostalgia policy maker' and a 'European identity contractor' (Cohen, 2007). ARTE is no stranger to nostalgic trends. Over several years, ARTE featured a special summertime programme entitled the 'Summer of ...' series. Launched in 2008, it revisited the past by playing musical hits from former decades. It began with 'Summer of the Sixties' (ARTE, 2013a), followed by 'Summer of the Seventies' (ARTE, 2013b) in 2009 and 'Summer of the Eighties' (ARTE, 2013c) in 2010. The 1990s being, perhaps, too close in time, the decision was made to discontinue the 'decades' theme and replace it with something more up to date. 'Summer of the Girls' came out in 2011 and 'Summer of Rebels' (ARTE, 2013e) in 2012. This sudden change illustrates the ambiguity of the nostalgic theme: where are the acceptable limits, especially in terms of time, of this sort of looking back? What content should be featured in trips back in time? How can these endeavours be successfully made relevant to the present? This example also raises the questions of what each 'generation' is all about (that of the 1960s, for instance) and, furthermore, which generation this type of programme is aimed at. This chapter studies the way ARTE functions as a 'time machine' by examining its policy of nostalgia within its concern with shaping European identity. 
Through its programmes, ARTE embodies a primary function of nostalgia: it recounts the past and it discusses origins. A short analysis of the focus of the Parallel History (Histoire Parallèle, ARTE, 1989-2001) programme will demonstrate this point. When one recalls certain events or facts, one necessarily excludes others: media both remember and forget (Luhmann, 2004). In this sense ARTE not only recalls the past, but also points to the accompanying notions of oblivion and memory. The programme Ce qui me manque ('What I Miss') will be a case in point in this chapter, underpinning the position it occupies in ARTE's policies of nostalgia. In a third and final section, this chapter will focus on ARTE's forms of 'counter-nostalgia'. If the channel tries to construct a tale based on European identity, with recourse to pictures of the past and to the power of oblivion, it misses its goal. A study of the programme Karambolage and the hybridisation phenomenon it features reveals the anticipation of a reality in the making, namely the reality of European identity.

\section{Remembering the past}

ARTE, founded nearly 20 years ago by a French-German partnership, can be regarded as the embodiment of a primary function of nostalgia. Its main objective is to recount the past, stressing the memory of the painful events shared by the two nations in question (Mink and Neumayer, 2007). The channel is well known for furthering the cause of reconciliation between the former enemies who fought against each other in both World Wars. Even today, ARTE specialises in documentaries dealing with this burdensome past. The former Histoire Parallèle programme, for instance, was emblematic of this early form of a 'grand' narrative of the past. Histoire Parallèle was particularly interesting insofar as it not only recalled and commemorated the past but also connected it with the present. The programme followed the events of the Second World War day 
by day, several decades after they happened. ARTE stands for "Association Relative à la Télévision Européenne', and the purpose assigned to the institution by its supervisors was to provide programmes intended for a 'European' public which ARTE was hoping to help bring about. One can, therefore, see this channel as a sort of 'European identity contractor', tasking itself with meeting the terms of a contract. The way it uses the past is part of what once was called counter-nostalgia. It stages a past which is seen as a foil, fraught with horror, and is thus rejected.

However, the channel is unable to state unequivocally what the 'European identity' actually is: it has not stabilised fully and seems to be constantly in the making, forever in the womb, in a way that is close to anthropologist Marc Abélès's idea of 'presentism' (2000). Defining European identity from the standpoint of this painful past while maintaining a view of what is to come is the most interesting feature of ARTE's 'nostalgia policy', which I propose to analyse with a particular focus on a number of productions of ARTE France's Research Workshop, such as Karambolage and Ce qui me manque. Histoire Parallèle can be classified as a 'brown soup' production. Programmes that deal with the World Wars are famous for attracting large audiences. This 'brown soup' was and is part and parcel of ARTE's nostalgia policy and is in tune with its sense of melancholia. Histoire Parallèle has a dark tone and, like most of ARTE's 'brown soup' productions, is in black and white. As emphasised by an article about Histoire Parallèle which appeared in L'Express, 'the War was for ARTE a flagship product' (Schifres, 2001). The programme was designed to attract an audience at minimal cost. Histoire Parallèle used to boast 1.5 million regular viewers. It seems to have been more than just a way to carry ARTE to the top of the ratings (Rostain, 2001): it appears to have been conceived as a staple of the nostalgia policy, designed to alleviate suffering. The programme aired weekly from 3 
May 1989 until September 2001 and was conceived by German and French historians, in particular Marc Ferro and Klaus Wenger. Its purpose was to show on screen, on either side of the Rhine, first on La SEPT, and later on ARTE, 'what the average Frenchman and the average German were allowed to see of the outside world 50 years ago, during the Second World war and in its aftermath, when television still did not exist' (Ferro, 1995). The programme was structured around three main guiding principles. The German title, Die Woche vor 50 Jahren ('A week, 50 years ago'), points to the first. It purported to show quite accurately, exactly 50 years on, what ordinary people used to see on the cinema screen. The programme's second important principle was that of integrity, the documents being delivered in their original condition without any cuts or editing. The third guideline was that of the 'French-German dual outlook' (Wenger, 1993), with images coming from German and French but also Soviet, American Japanese and other European newsreels (Ferro, 1993). Occupied France, under strict Nazi censorship, produced no news programmes of its own. Interestingly, the two presenters, Ferro and Wenger, were from different generations. The latter was born just after the Second World War, but the former lived through it, both as a witness and as a resistance fighter, and experienced its consequences (Garçon, 1992).

The historian Matthias Steinle offered an in-depth study of these questions at a symposium on history and the cinema which took place in Paris in 2010 (Steinle, 2010). The first principle upon which Histoire Parallèle was built is all-important to ARTE's nostalgia policies. As it told of events which occurred exactly 50 years ago to the day, Histoire Parallèle impacted the contemporary viewer's present (Ferro and Planchais, 1997). In Steinle's (2010) words, the revolutionary thing about Histoire Parallèle is that it is inscribed in another temporality; it is history in keeping with present-day life, history in real time, week after week. This original 4 
concept interlocked the past with the present, which caused a journalist to write that, while French lorry drivers were disputing points on their driving licences, Hitler was launching his attack against the Caucasus (Schifres, 2001). It also came closer to the format of a television series or serial, with moments of suspense and tension. However, it had one remarkable feature: the events seemed fresh, since they were being revisited 50 years later and shown in a novel way, but they were also predictable, since they were part of a story whose outcome was known to all viewers. Marc Ferro summed up this paradox very well when he said, in his introduction to the first episode of Histoire Parallèle, 'In some ways, I experienced the war twice, once as a resistance fighter and a witness, and once as a historian, and it is almost like the second time is proving the harder' (Histoire Parallèle, 1). The nostalgia policy implemented by ARTE turned the channel into an investigative tool for understanding the past. It was history in the Greek sense of 'istoria', which Herodotus saw as an 'inquiry', an 'exploration'. Steinle seems to be right when he says that the images of Histoire Parallèle at once gained and lost meaning. They could be considered simultaneously as active with regard to history and as a framework for what was observable and communicable. He calls them 'palimpsest images' (Steinle, 2010).

\section{Media are time machines: They remember and forget}

When one recalls certain events or facts, one necessarily leaves others aside. ARTE's programmes showed nostalgia as feeding on oblivion, on a feeling of something missing, the frustration of remembering what once was but is forever gone. With Ce qui me manque, the channel tried to explore that complex feeling. This aspect of their nostalgia policy was conceived by ARTE as a means to lend consistency to the 'European identity' they desired to bring about. Ce qui me manque came as two distinct series. In Part I, two individuals, one German and one 
French, no longer living in their native countries but across the Rhine from them, were asked to evoke in a few words, then to present on screen, an object they missed, explaining how it was used. Here was a television format that palliated oblivion by showing the absence of something causing a person to feel nostalgic. In the conversations I had with the producers, they explained that the TV presentation of these missed objects was significant on two levels: first on a subjective level, as they belonged to one person in particular, and second on a social level, as they reflected their owner's membership of a certain group. In Ce qui me manque Part I, several German and French expats presented one particular object that they missed in their adopted countries in order to help viewers on either side of the Rhine grasp an aspect of their identities. Part II confirmed and broadened this line of action. At first limited to French and German objects, the concept widened to include all countries of the European zone. From March 2007, on the occasion of the 50th anniversary of the Treaty of Rome, these small modules were vested with a greater mission: to show a European identity not only based on the French-German link but extended to the other European member-countries. Part II, in the words of Claire Doutriaux, the promoter of the programme, displayed 'small pieces of Europe, with all its cultures, of its languages, its life ... Ce qui me manque embodies Europe in its various aspects' (ARTE, 2013f). Two features emerge from this analysis. Bringing to the fore objects that people had forgotten about was the way ARTE, as the contractor first of a German-French identity and later of a European one, designed its second nostalgia policy. It was by adding up these nostalgic moments, these missed objects, that a draft of European identity was constituted, like a mural showing many faces. The notions of a mural and of an addition were clearly emphasised in the travelling video exhibition that Claire Doutriaux designed and presented (for instance, in Paris during such events as the Nuit Blanche at the Maison de l'Europe on 4 October 2010): 'We are 
trying, as a complement to the broadcast on ARTE, to organise a travelling exhibition across Europe for this series, with two dozen screens showing 20 fixed faces becoming animated in turn, and forming a one-hour loop.' Claire Doutriaux could be seen as a European identity contractor. The latter concept seems to be particularly appropriate: it designates a group of individuals, or social groups, assuming a political role at the service of all. They embrace an idea and find ways to make it fruitful. Political scientists such as Cohen (2007) and Aldrin (2011), as well as the ethnologist Mazé (2010), make use of this concept. For instance, the thesis is all about the emergence of so-called 'European' museums on the Continent. Mazé (2010) found a number of museum curators who were applying the concepts of European memory and identity to their particular realms.

ARTE is like an identity contractor with a mission to represent Europe and to reveal its many aspects to the public. It thus implements different forms of nostalgia policies. This chapter has shown how the channel tried to explore the past in a new way by looking back at recent history and linking it with the present, thus offering a form of 'real-time history'. That first reflection singled out memory, oblivion, emptiness and longing for the past as being inherent in the channel's sense of nostalgia. Thus, in a way, ARTE seems inescapably hesitant about the formulation of the European identity it was hoping to promote. To conclude, I will now shed light on one final modality of nostalgia: ARTE's 'counter-nostalgia'.

\section{Counter-nostalgia}

When I was inquiring into the matter, interviewing ARTE staff members and attending their meetings, I was struck by their recurring concern with exactly how to define their 'European 
mission'. The topic was repeatedly broached and was the source of great perplexity. Even today, this question remains quite problematic for a number of ARTE programmers (Turner, 1974). One strategy they often used to elude the question was to relegate it to the very end of meetings (Hartemann, 2011). Time constraints then meant that they would put it off to the next meeting, and so on, again and again. The question could thus be kept pending over a long period. I noticed another way of solving the 'European identity' dilemma. It consisted in agreeing on at least one thing, namely that European identity is as yet unfinished, and ARTE is the matrix or mould in which it will be shaped. So, short of being able to adopt a common position on what definition to give for Europe, the managers of ARTE agree to see it as 'still in progress'. And so, at the end of their meetings, they keep raising, almost ritually, the question of the contents to be given to European identity: 'and about Europe, what do we do?' I call this attitude 'counter-nostalgia', or 'presentism', in reference to the notion developed by Abélès (2000) and Zawadzki (2008). It clarifies the issue and suggests that now, as we speak, European identity is still evolving, still pending. For some ARTE executives, meanwhile, it seeks its definition through this very process. Yet these reservations should be toned down. Various valid projects have been designed and have given birth to such productions as the Visages d'Europe (Faces of Europe) documentaries. In the introduction to the catalogue Faces of Europe, Jose Durão Manuel Barroso writes: 'I am delighted that ARTE has completed the Faces of Europe-collection that was successfully launched for the 50th anniversary of the Treaty of Rome. The catalogue contains 135 documentary portraits of citizens from every country in Europe, of all ages and conditions' (ARTE, 2008). But other elements of 'counter-nostalgia' are conspicuous in the creations and hybridisations devised by the creators of such programmes as Ce qui me manque and Karambolage. The idea that governs these counter-nostalgic programmes is the desire to project 
a hybrid image, showing European identity as a mix of cultures. This is no longer to be found solely in the German-French relationship, or only in membership of the European continent. $\mathrm{Ce}$ qui me manque and Karambolage have also discussed objects brought here by people from outside Europe. Take the case of Alice Diop (ARTE, 2013g), a French woman aged around 20 and of Senegalese origin. Alice discussed her traditional African wide-toothed comb. These programmes cast a new light on the question of European identity by focusing on items from outside the European continent. The presentation of these objects creates cultural hybridisations. Diop explains how her comb travelled from Senegal to France and was responsible for changes in the behaviour of both French-born women of African descent and hairdressers. The comb can be seen as a new European object, setting new programme topics and helping to shape European identity. Although ARTE implements nostalgia policies in order to accomplish its mission of building a European identity, the channel nevertheless seems unable to decide between various options. It is unsure whether it should be offering a vision of the past, emphasising oblivion, struggling with 'presentism' or looking forward to a Europe that still does not exist. Because of the complexity of its relation to time, ARTE rightly deserves to be seen as a time machine.

\section{References}

Abélès, M. (1992) La vie quotidienne au Parlement européen. Paris: Hachette.

Abélès, M. (2000) 'L’Europe: un objet conceptuel mal identifié', in A. Abensour (ed.) Le XXème siècle en France, Art, Politique, Philosophie. Paris: Berger Levrault, pp. 67-83.

Aldrin, P. and Dakowska, D. (2011) 'Légitimer l'Europe sans Bruxelles? Un regard sur les petits entrepreneurs d'Europe, entre décentrement et recentrages'. Politique Européenne, 34, pp. 7-35. 
ARTE (2008) Visages d'Europe/Faces of Europe: The Human Face of Europe. Catalogue, with an introduction by Jose Durao Manuel Barroso, D.G. Communication, Service audiovisuel, ARTE Edition.

ARTE (2013a) Summer of the Sixties, http://www.arte.tv/fr/summer-of-the-sixties/3194472.html (accessed 31 May 2013).

ARTE (2013b) Summer of the Seventies, http://www.arte.tv/fr/2012036.html (accessed 31 May 2013).

ARTE (2013c) Summer of the Eighties, http://www.arte.tv/fr/a-l-antenne/2616674.html (accessed 31 May 2013).

ARTE (2013d) Summer of the Girls, http://www.arte.tv/fr/summer-of-girls/3864680.html (accessed 31 May 2013).

ARTE (2013e) Summer of the Rebels, http://www.arte.tv/fr/summer-of-rebels/6648126.html (accessed 31 May 2013).

ARTE (2013f) Ce Qui Me Manque, http://www.arte.tv/presentation-generique/1506550.html (accessed 31 May 2013).

ARTE (2013g) Karambolage, http://www.arte.tv/fr/europeens/karambolage/Emission-du-26juin2011/3980748,CmC=3980902.html (accessed 31 May 2013).

ARTE (2013h) Ce Qui Me Manque, http://www.arte.tv/fr/europeens/ce-qui-me-manque2/Presentation---Generique/1506550.html (accessed 31 May 2013).

ARTE, Histoire Parallèle, numéro 1, Marc Ferro, Klaus Wenger, Emission Histoire Parallèle, shown 3 September 1989. 
Cohen, A. et al. (2007) 'Esprit d'Etat, entrepreneurs d'Europe', in Actes de la Recherche en sciences sociales, 166-167, pp. 5-13.

Dayan, D. (2006) 'Quand montrer c'est faire', in D. Dayan (ed.) La terreur spectacle, Terrorisme et television. Bruxelles: INA De Boeck, pp. 165-184.

Dayan, D. and Katz, E. (1996) La télévision cérémonielle. Paris: PUF.

Ferro, M. (1993) Cinéma et Histoire. Collection Folio/Histoire, 55. Paris: Gallimard.

Ferro, M. (1995) Revivre l'histoire autour d'Histoire Parallèle, with the cooperation of Claire Babin. Paris: ARTE Editions/Liana Levi.

Ferro, M. and Planchais, J. (1997) Les médias et l'histoire, le poids du passé dans le chaos de l'actualité. Paris: CFPJ Editions.

Ferro, M. and Wenger, K. (1989) Emission Histoire Parallèle, number 1, shown 3 September 1989, ARTE.

Garçon, F. (1992) 'La réussite d'Histoire Parallèle'. Cinéma et Histoire. Autour de Marc Ferro, CinémAction, (65), pp. 58-61.

Hartemann, A. (2011) 'Les relations franco-allemandes au sein de la chaîne culturelle à vocation européenne ARTE. Dissensions et modes de résolution des conflits au prisme de l'analyse stratégique et de la sociologie des organisations'. Trajectoires, http://trajectoires.revues.org/818 (accessed 31 May 2013).

Luhmann, N. (2004) Die Realität der Massenmedien. Wiesbaden: Verlag für Sozialwissenschaften. 
Mazé, C. (2010) Mettre l'Europe au musée: une affaire d'État? Ethnographie et sociohistoire du chantier des « musées de l'Europe (1980-2010), PhD defended 22 October 2010, EHESS-ENS.

Mink, G. and Neumayer, L. (2007) L’Europe et ses passés douloureux. Paris: La Découverte.

Rostain, S. (2001) 'La fin de l'histoire en temps réel'. Libération, le 01.09.2001, http://wwwliberation.fr/medias/0101384945-la-fin-de-1-histoire-en-temps-reel (accessed 31 May 2013).

Schifres, A. (2001) 'La fin de l'histoire'. L'Express, http://www.lexpress.fr/informations/la-finde-1-histoire_645421.html (accessed 31 May 2013).

Steinle, M. (2010) 'L'expérience d'Histoire Parallèle'. Intervention dans le cadre du colloque international Le cinéma au prisme de l'histoire. Les laboratoires 'Cinéma et Histoire', EHESS, 20-21 May 2010, Paris.

Turner, V. (1974) Dramas, Fields and Metaphors. Symbolic Action in Human Society. New York: Cornell University Press.

Wenger, K. (1993) ، “Histoire parallèle”, eine Dokumentationsserie über den Zweiten Weltkrieg von hoher Aktualität', in U. Koch (ed.) Deutsch-französische Medienbilder: Journalisten und Forscher im Gespräch/Images médiatiques franco-allemandes. München: R. Fischer, pp. 243246.

Zawadzki, P. (2008) 'Les équivoques du présentisme’. Esprit, pp. 114-134. 